pISSN : $2301-8968$

JEKT \ $14[1]: 97-10$

eISSN : $2303-0186$

\title{
Are Wealthier People Healthier? An Analysis to Indonesian Baby Boomers
}

\author{
Axellina Muara Setyanti \\ Nayaka Artha Wicesa \\ Universitas Brawijaya
}

\begin{abstract}
The elderly population in Indonesia has doubled in the last five decades, along with an increase in life expectancy and mortality. Those who were born in the 1940s to 1960s or the baby boomer generation are those who are in old age now. There are many studies that analyze the relationship of wealth to one's health level, but not many have looked specifically at the elderly population. The objective of this study is to determine the effect of wealth on elderly's health condition. Using binomial logistic regression, this study found that the highest average health probability of the elderly was 78.96 percent, i.e. those with working status, above average income and no expenditure on unhealthy commodities such as cigarettes, while the average health probability the lowest was 52.44 percent, i.e. those with non-work status, below-average income, and having expenditures for unhealthy commodities. This study found that wealth affects the health level of the elderly. These conclusions, accompanied by aging conditions in a country have policy implications that must consistently implement efforts to improve social welfare for the elderly, thereby creating healthy and active aging.
\end{abstract}

Keywords: elderly, health, wealth, baby boomer

JEL Classification: J14, I15

\section{Apakah Orang yang Lebih Kaya Lebih Sehat? Analisis terhadap Generasi Baby Boom di Indonesia}

\begin{abstract}
ABSTRAK
Populasi lansia di Indonesia meningkat dua kali lipat dalam lima dekade terakhir, seiring dengan peningkatan angka harapan hidup dan kematian. Mereka yang lahir tahun 1940-an hingga 1960-an atau generasi baby boomer adalah mereka yang kini sudah berusia lanjut. Ada banyak penelitian yang menganalisis hubungan kekayaan dengan tingkat kesehatan seseorang, tetapi tidak banyak yang secara khusus meneliti populasi lansia. Penelitian ini bertujuan untuk mengetahui pengaruh kekayaan terhadap kondisi kesehatan lansia. Dengan menggunakan regresi logistik binomial, penelitian ini menemukan bahwa rata-rata probabilitas kesehatan lansia tertinggi adalah 78,96 persen, yaitu mereka yang berstatus bekerja, berpenghasilan di atas rata-rata dan tidak ada pengeluaran untuk komoditas tidak sehat seperti rokok, sedangkan ratarata probabilitas kesehatan lansia paling rendah adalah 52,44 persen, yaitu mereka yang
\end{abstract}


berstatus tidak bekerja, berpenghasilan di bawah rata-rata, dan memiliki pengeluaran untuk komoditas yang tidak sehat. Penelitian ini menemukan bahwa kekayaan mempengaruhi tingkat kesehatan lansia. Kesimpulan tersebut, yang disertai dengan kondisi penuaan di suatu negara memiliki implikasi kebijakan yang harus secara konsisten melaksanakan upaya peningkatan kesejahteraan sosial bagi lanjut usia sehingga tercipta generasi lanjut usia yang sehat dan aktif.

Kata kunci: lansia, kesehatan, kekayaan, baby boomer

Klasifikasi JEL: J14, I15

\section{INTRODUCTION}

Declining fertility rates meet steady improvements in life expectancy over the latter half of the 20th century have created significant growth in the world's oldest population (DaVanzo, 2001). Evidently, in the span of five decades (1971-2019), the percentage of elderly people in Indonesia increased by about twice, to around 25 million people or 9.6 percent of the total population (BPS, 2019). Moreover, the UN has predicted that the percentage of Indonesians over 60 years old will reach 25 percent in 2050 or nearly 74 million elderly people (Nasir, 2015).

The definition of old age based on Law Number 13 Year 1998 is someone who has reached the age of 60 (sixty) years and above, meaning that these elderlies are born before the 1960s. The generation born between 1946-1964 is commonly called the baby boomer generation (Lancaster and Stillman,
2002; Martin and Tulgan, 2002). The baby boom generation emerged as an important group in changing populations. (Ogg and Bonvalet, 2011). Mannheim (1952) found a gap between the values offered by the older generation and the reality produced by the younger generation, this has an impact on the formation of individual characters.

As stated by DaVanzo (2001) the health of elderly populations is a critical issue and influences outcomes in all of the other policy areas affected by aging. Similarly, the elderly population in Indonesia continues to grow with advances in the health sector that increase life expectancy. In the period 2010-2015, life expectancy reached 70.1 years and is projected to be 72.2 years in 2030-2035. This will not only have an impact on the health sector itself, but also economically and socially. Despite an increase in life expectancy and a 
reduction in mortality, there are still about half of the total elderly who are being repaired. Elderly morbidity rate decreases every year. In 2019, one in four elderly people will get sick in the end, but the awareness of the elderly towards health complaints they suffer is quite high (BPS, 2019). In terms of the Total Dependency Load (ABK) of the elderly in Indonesia in 2019 received by 15.01, an increase from 11.95 in 2010 means the burden of productive population on the elderly is relatively high. However, in terms of economic activity of the elderly, it is known to be 49.39 percent, meaning that one in two elderly Indonesians still work (BPS, 2019).

There are many studies that discuss the relationship between health and wealth status in the elderly through two estimates. The relationship between wealth and health is interrelated and requires decision makers to realize the core channels for achieving growth and development. The role of health is very important for the nation's economic growth and wealth (Salman and Atya, 2012). In line with Feinstein and Ho
(2000), health conditions and income levels can be used with each other and a significant increase in household assets and their utilization. The recent findings in Britain show the difference in life expectancy between the top and bottom social classes has increased from five to nine years (Deaton, 2002). High-income elderly usually finds alternative ways to pay for health care costs usually through the allocation of funds without having to reduce their assets and savings compared to those on low incomes. Older people with lower income pays for health care costs through their savings and not from their income.

Likewise, in the consumption of boomers, they tend to consume by considering the durability, quality, and value of goods. They tend to buy goods that last a long time (Leach et al, 2013), which will depend on their wealth until old age. Willetts (2010) highlights the economic and political power of a boomer generation where this generation may now dominate almost all the important institutions in the country: it has the most wealth and 
strength. While Harkin and Huber (2004) stated, many baby boomers began to enjoy a combination of wealth, health, and longer life giving them a new phase in life.

Income and wealth are socioeconomic indices that measure the economic situation directly. Of course, income effects, which affect health, are valid insofar as they are consumed or converted to promote a more pleasant living environment. Labor conditions, the environment, adequate physical activity, good food and other healthy management are these income effects (Park et al, 2009). Furthermore, through financial channels, savings have a direct effect on health. In poor countries with low savings, the challenge is to protect the sick. The second channel involved is education, because people with better levels of education are able to protect their health, and can use preventive and curative medical systems. Third, financial institutions are represented in: the public sector, such as, hospitals and government clinics, and university hospitals, while the private sector such as: private insurance companies, unions, non-governmental organizations (NGOs) and the household sector (Salman and Atya, 2012).

The relationship between wealth and health can be explained in a material and psychosocial way. Money buys people the main needs they need for health such as shelter, warmth and food. This also allows them to avoid, or repair, potentially dangerous 'poisons', such as living in a noisy or polluted poor environment. This implies a basic level of financial resources needed for good health, but the evidence shows that there is a more stratified association: the more money people have the better their health (Benzeval et al, 2014). Empirically, the socioeconomic status of individuals and the environment are interrelated with the health of individuals and populations because the local economy determines access to jobs, trade, schools, and other resources that allow families to enjoy economic success and the benefits of environmental-based health (Doubeni et al, 2012).

In another study, population health was affected not only by the 
economic well-being of individuals and households, but also by the health and economy of their communities. People who are unable to live in healthier and more desirable areas often struggle with challenges related to various factors related to community-level health: People in low-resource environments often have limited access to nutritious food sources, such as supermarkets that sell products fresh and other healthy food choices (Bhattacharya et al, 2004; Morland and Susan, 2007). Low-income people tend to have limited access to green spaces, recreation programs, and facilities for regular exercise and active life. (Dahmann et al., 2010). Low resource environments often face shortages of employment opportunities, as well as high-quality primary care providers and clinical facilities (Zhang et al, 2008). Low-income residents also tend to be unable to live in pollutantfree environments and may need to live near highways that are busy with vehicle emissions, factories with chimneys and water emissions, bus stops, and other sources of air and pollution (Mohai et al, 2009; Brulle and
David, 2006). This paper aimed to find the relationship of economics variables representing wealth on baby boomer's health in Indonesia.

\section{MATERIALS AND METHOD}

This research uses binomial logistic regression method, that is used to describe the relationship between dependent variables that have two categories with one or more independent variables on a category or continuous scale. The dependent variable in this study is health with categories 1 and 0 . The population in this study is the entire Indonesian population born between 1946-1964, referring to the definition of baby boomers themselves, while the generation before the boomers is the population born before 1946. The data are taken from Indonesian Family Life Survey Wave 5 (IFLS Wave 5). Thus, 4769 samples aged 50 to 68 years were obtained and 1670 samples aged over 68 years when surveyed in 2014 at IFLS Wave 5. This study uses health variables as the dependent variable while the 
independent variables are income, expenditures for unhealthy commodities, such as cigarettes, tobacco, alcoholic beverages, and recreation expenses. In addition, control variables such as work status, retirement status and social participation in health are used. The model specifications are as follows:

$\ln \left(\frac{H_{i}}{1-H_{i}}\right)=H_{i}=\beta_{0}+\beta_{1} I_{i}+\beta_{2} W_{i}+$ $\beta_{3} R_{i}+\beta_{4} S P H_{i}+\beta_{5} U E_{i}+\beta_{6} R E_{i}$

The operational definition of each variables are specified below:

Table 1 Operational Definition of Research Variables

\begin{tabular}{|c|c|c|}
\hline Variable & Definition & Value \\
\hline $\mathrm{H}$ & Dummy, representing health probability of elderly & $\begin{array}{l}1=\text { healthy ; } 0=\text { not } \\
\text { healthy }\end{array}$ \\
\hline $\mathrm{I}$ & Monthly income of elderly & million rupiah \\
\hline W & Dummy, representing the working status of elderly & $1=$ working $; 0=$ others \\
\hline $\mathrm{R}$ & Dummy, representing the retirement status of elderly & $1=$ retired $; 0=$ others \\
\hline $\mathrm{SPH}$ & Social participation related to health & $\begin{array}{l}\text { Number of activities } \\
\text { participated }\end{array}$ \\
\hline UE & Unhealthy commodity expenditure per month & million rupiah \\
\hline RE & Recreational expenditure per month & million rupiah \\
\hline $\mathrm{i}$ & individual & \\
\hline
\end{tabular}

Source: IFLS 5, processed

Equation (1) is a binomial logistic where regression model. Estimation results in the coefficient of the logistic regression $P_{i}=\frac{1}{1+e^{-Z_{i}}}$ model cannot be interpreted directly so an antilog value must be sought from each coefficient (odds ratio).

Ratio $=\frac{P_{i}}{1-P_{i}}=$ $e^{\beta_{0}+\beta_{1} I_{i}+\beta_{2} W_{i}+\beta_{3} R_{i}+\beta_{4} S P H_{i}+\beta_{5} U E_{i}+\beta_{6} R E_{i}}(2)$
Using logistic regression coefficients above, the probability of someone's healthier or unhealthier will be predicted. 


\section{RESULTS AND DISCUSSION}

From a historical perspective, population aging represents a human success story. As education and income levels and access to safe, effective contraception have risk, increasing numbers of individuals have been able to achieve their lower reproductive goals. Moreover, most people live much longer lives, in better health, and with different personal expectations than their forebears (NCBI, 2001). Elderly population continues to increase as advances in the health sector are characterized by increased life expectancy and decreased mortality. At present the elderly population in Indonesia is 9.6 percent of the total population, doubling from the 1970s.
In the 1960s, Indonesia was in the era of an extra ordinary number of babies, known as baby boom era. This period lasted until the initiation of the family planning program in the 1970s which then succeeded in suppressing population growth through birth. Improving the availability of food sources and improving health reduces the risk of disease and increases the life expectancy of the population. The results of these improvements, now bring babies in the era of the baby boom aging, thus widening the pyramid to the elderly population groups in many countries in the world, including Indonesia. Some general description of elderly people in Indonesia and their health condition are as follows:

Table 2 Elderly Populations in Indonesia and Their Health Conditions, 2019

\begin{tabular}{lcccc}
\hline \multicolumn{1}{c}{ Characteristics } & \multicolumn{4}{c}{ Age Groups } \\
\cline { 2 - 5 } & $\begin{array}{c}\text { Pre-elderly } \\
\mathbf{( 4 5 - 5 9 )}\end{array}$ & $\begin{array}{c}\text { Young } \\
\text { Elderly (60- } \\
\mathbf{6 9 )}\end{array}$ & $\begin{array}{c}\text { Middle Elderly } \\
\mathbf{( 7 0 - 7 9 )}\end{array}$ & $\begin{array}{c}\text { Late } \\
\text { Elderly } \\
(\mathbf{8 0 +})\end{array}$ \\
\hline Total of Elderly & 17,16 & 6,12 & 2,66 & 0,82 \\
\hline Based on Residence & & & 2,49 & 0,72 \\
Urban & 17,14 & 5,86 & 2,86 & 0,94 \\
Rural & 17,19 & 6,46 & & \\
\hline
\end{tabular}

Based on Health Condition 


\begin{tabular}{|c|c|c|c|c|}
\hline Experiencing Health Problem & $\mathrm{n} / \mathrm{a}$ & 48,75 & 54,85 & 56,31 \\
\hline Experiencing Sickness & $\mathrm{n} / \mathrm{a}$ & 26,96 & 27,03 & 22,86 \\
\hline Healthy & $\mathrm{n} / \mathrm{a}$ & 24,29 & 18,12 & 20,83 \\
\hline $\begin{array}{l}\text { Based on Health Cure } \\
\text { Treatment } \\
\text { Self-medication }\end{array}$ & $\mathrm{n} / \mathrm{a}$ & 41,02 & 37,91 & 39,87 \\
\hline Outpatient & $\mathrm{n} / \mathrm{a}$ & 24,05 & 25,46 & 25,55 \\
\hline $\begin{array}{l}\text { Self-medication and outpatient } \\
\text { treatment }\end{array}$ & $\mathrm{n} / \mathrm{a}$ & 31,70 & 33,01 & 29,32 \\
\hline $\begin{array}{l}\text { Not doing self-medication and } \\
\text { outpatient treatment }\end{array}$ & $\mathrm{n} / \mathrm{a}$ & 3,24 & 3,62 & 5,27 \\
\hline
\end{tabular}

Source: Susenas BPS (2019)

The concept and definition of health elderly people who are sick is also called complaints used in Susenas is the morbidity rate. Half of the elderly in condition of a person suffering from health or mental health problems, both due to disorders / illnesses that are often experienced by residents such as fever, colds, diarrhea, dizziness, headaches, as well as due to acute illness, chronic illness, accidents, criminality or other indications. Health problems do not always result in disruption of daily activities. However, the occurrence of health complaints and types of complaints experienced by residents can describe the level / degree of health roughly. Meanwhile, the condition of illness is a health problem that interferes with daily activities so that it cannot carry out activities normally as usual. The percentage of Indonesia experience health complaints and the percentage increases with increasing age.

The elderly in Indonesia are dominated by young elderly who are in the age range of $60-69$ years, which is $6.12 \%$ of the total population of Indonesia. The number of elderly living in rural and urban areas is relatively balanced. Based on their health condition, more than half the elderly experience health complaints. The older the elderly, the percentage of health complaints is also increasing. But not so with those who experience pain. The group that experienced the lowest percentage of illness was elderly. The average elderly who are in a healthy 
condition is in their 20s. Among the several medical treatments, the most self-medication is chosen by the elderly.

\section{Estimation Results}

Before estimating binomial logistic regression, a goodness of fit test was performed using the Hosmer and Lemeshow Test. The purpose of this test is to determine whether a model formed is correct or not. A model is said to be appropriate if there is no significant difference between the model and its observational value. If the test results show that the model formed is not right, then it must add interaction variables between independent variables in the model.
The results of the model feasibility test using Goodness of Fit Test show that the chi-square is 1940.47 and the probability value 0.3253 is more than the $5 \%$ significance level. That is, $\mathrm{HO}$ is accepted. So it can be said that the model is able to predict the value of its observations. In other words, the model formed is correct. That is, the model is worth estimating using binomial logistic regression with the maximum likelihood method, which is a method for finding the regression coefficients so that the probability of occurrence of the dependent variable can be as high as possible.

Table 3 The Estimation Results of Binomial Logistic Regression

\begin{tabular}{|c|c|c|c|c|c|c|c|c|}
\hline \multirow{2}{*}{ Variables } & \multirow{2}{*}{$\beta$} & \multirow{2}{*}{ S.E. } & \multirow{2}{*}{ Wald } & \multirow{2}{*}{ Df } & \multirow{2}{*}{ Prob } & \multirow{2}{*}{$\operatorname{Exp}(\beta)$} & \multicolumn{2}{|c|}{ 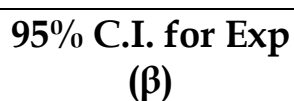 } \\
\hline & & & & & & & Lower & Upper \\
\hline Constant & $0.148^{*}$ & 0.075 & 1.96 & 1 & 0.051 & $1.159^{*}$ & 0.999 & 1.345 \\
\hline Income & $0.171^{* * *}$ & 0.058 & 2.91 & 1 & 0.004 & $1.186^{* * *}$ & 1.057 & 1.332 \\
\hline Working & $0.764^{\star * *}$ & 0.057 & 13.21 & 1 & 0.000 & $2.146^{* * *}$ & 1.916 & 2.404 \\
\hline Retired & 0.004 & 0.083 & 0.06 & 1 & 0.953 & 1.004 & 0.852 & 1.184 \\
\hline $\begin{array}{l}\text { Social } \\
\text { Participation in } \\
\text { Health }\end{array}$ & 0.016 & 0.022 & 0.75 & 1 & 0.452 & 1.017 & 0.973 & 1.062 \\
\hline
\end{tabular}




\begin{tabular}{|c|c|c|c|c|c|c|c|c|}
\hline $\begin{array}{l}\text { Unhealthy } \\
\text { Expenditure }\end{array}$ & $-0.764^{* *}$ & 0.380 & -2.01 & 1 & 0.045 & $0.465^{* *}$ & 0.220 & 0.981 \\
\hline $\begin{array}{l}\text { Recreational } \\
\text { Expenditure }\end{array}$ & 0.729 & 0.530 & 1.38 & 1 & 0.169 & 2.073 & 0.733 & 5.860 \\
\hline Pseudo $\mathrm{R}^{2}$ & & & & & 0.025 & & & \\
\hline Prob Chi ${ }^{2}$ & & & & & 0.000 & & & \\
\hline
\end{tabular}

note: level of significance ${ }^{* \star *} 1 \%,{ }^{* *} 5 \%,{ }^{*} 10 \%$

Source: IFLS (processed using STATA)

The estimation results show that wealth related variable, income, affect elderly's health condition. Income has a significant positive effect on health at a significance level of $1 \%$, so that if income increases by 1 million IDR, then it is likely that health will increase by 1,186 times. The greater the income, the lower the likelihood of illness and premature death. Studies in America show that at all income levels those with higher incomes have better levels of health. Not only income (income and other income earned each year) is associated with better health, but wealth (assets) also affect health (Woolf et al, 2015). As in the findings of Tajvar et al (2008), economic status is recognized as the most important predictor of quality of life for elderly human resources among other factors studied. Having enough money is important for quality of life, not only to fulfill and fulfill the basic needs of life, but also is a very influential factor for participating in society, to enjoy hobbies, holidays, luxury and luxury for the community. the elderlies are free from worries about emergencies in life and unexpected costs in the future. Thus, increasing the income of low-income community members is often proposed by improving their health, and hence reducing health inequalities with better income groups (Benzeval et al, 2014).

Working status has a significant positive effect on health at a significance level of $1 \%$, so the chances of being healthier for those who work are 2,146 times higher than those who do not work. Work and related actions may also be the primary form of physical 
activity and exercise for many individuals. To the extent that the shift from work to retirement leads to a decline in the frequency or intensity of physical activity, retirement may lead to worse health outcomes, ceteris paribus (Dave et al, 2006). A direct pathway is the impact of work on our health through our incomes. A report from Statistics Canada about health-related quality of life they found the gaps were even greater. Men in the highest income group had 14.1 more years of healthy living than those in the lowest income group. That gap between women in the lowest and highest income groups was 9.5 years (Block, 2010). In Indonesia, the percentage of working elderly people reaches 49.39 percent in 2019 (BPS, 2019). In other words, 1 in 2 elderly people still work in their old age. This shows that not a few elderly people who still want to be productive to fill their old days.

$$
\text { Spending on unhealthy }
$$
commodities has a significant negative effect on health at a significance level of $5 \%$, so that if spending on unhealthy commodities increases by Rp. 1 Million, then the likelihood of being healthy will decrease by 0.465 times. Given the health conditions of the elderly who are vulnerable to disease, healthy behaviors such as diligent exercise and not smoking, need to be applied. The 2019 Susenas results show that 24.30 percent or almost a quarter of the elderly smoke, both electric and tobacco smoking (BPS, 2019), even 22,15 percent still smoke with intensity every day. Assuming other factors are considered constant, older people who smoke have a higher health risk than those who don't smoke. It is linear with Tiainen (2018) that one of the factors which influence health is risk behavior, can be smoking, eating unhealthy food, drinking alcohol etc. These risk behaviors are more common in lower socioeconomic groups. Marmout (1999) previously found that the percentage of those with lower incomes or less education smoking is higher than of those who are well educated or earn more.

Retirement status, social participation in health and spending on recreation have no significant effect on health, but have a positive correlation 
on health. Interestingly, even though work and retirement status have a positive correlation with health, there is a higher tendency for employment compared to retirement. The assumption that retirement may affect physical and psychological well-being is based on the idea that retirement is a major life transition, which results in social-psychological transformation (Kim and Moen, 2002). The decision to retire is affected by a number of factors, including the availability of health insurance, Social Security eligibility, financial resources, and spousal interdependence. Several studies have also pointed to health status as a significant determinant. Workers in poor health, who suffer from activity limitations and chronic health conditions, were found to retire earlier than those who were healthy (Belgrave et al., 1987; McGarry, 2004). Szinovacz and Davey (2004) find that depressive symptoms increase for post-retirement women, especially if retirement is perceived as abrupt or forced. The transition from work to full retirement, by reducing the degree of social interaction, may have a negative effect on mental and physical health (Putnam, 2000; Saffer, 2005). Previous research has demonstrated a consistent and positive relationship between leisure time physical activity. Moderate and high levels of physical activity reducing mortality risk by upwards of 20 and 30\% (Nocon et al., 2008; Löllgen et al., 2009 ).

While on the recreational expenditure aspect, as Mueller et al (2019 a) found, a hundred-dollar increase in 2010 dollars in per capita parks and recreation operational expenditures was associated with an average decrease in morality of 3.9 and 3.4 deaths per 100,000 respectively, that means impove health condition. On his another research, he found that higher levels of parks and recreation spending were associated with higher levels of self-rated health for adults (Mueller et al, 2019 b).

Based on the $\mathrm{Chi}^{2}$ probability, all independent variables simultaneously have a significant effect on health. Then the Pseudo R2 test results show that the ability of the independent variable in 
explaining the dependent variable is $2.5 \%$, while the rest is explained by other variables outside the model. A low $R^{2}$ value in the binomial logistic regression model is normal, because the data distribution only lies between two extreme points, namely 0 and 1 .

$$
\begin{aligned}
& \ln \left(\frac{H}{1-H}\right)=Z_{i}=0.148+0.171 I+0.764 W+ \\
& 0.004 R+0.016 S P H-0.764 U E+0.729 R E
\end{aligned}
$$

Based on equation (4), health probabilities can be calculated by classifying several groups as follows:

Table 4 Health Probabilities by Several Groups

\begin{tabular}{lc}
\hline \multicolumn{1}{c}{ Groups } & Probability \\
\hline All samples & $63.35 \%$ \\
Actively working & $70.80 \%$ \\
$\begin{array}{l}\text { Actively working; Income above average } \\
\begin{array}{l}\text { Actively working; Income above average; Has no expenditures for } \\
\text { unhealthy commodities }\end{array}\end{array}$ & $78.50 \%$ \\
$\begin{array}{l}\text { Actively working; Income above average; Has expenditures for } \\
\text { unhealthy commodities }\end{array}$ & $78.96 \%$ \\
$\begin{array}{l}\text { Retired } \\
\text { Retired; Income below average }\end{array}$ & $77.85 \%$ \\
$\begin{array}{l}\text { Retired; Income below average; Has no expenditures for unhealthy } \\
\text { commodities } \\
\text { Retired; Income below average; Has expenditures for unhealthy } \\
\text { commodities }\end{array}$ & $53.60 \%$ \\
\hline
\end{tabular}
Source: IFLS (processed using STATA)

Table 3 shows the average health probabilities of several groups. For the whole sample, the average health probability was $63.35 \%$. The highest average health probability is $78.96 \%$, i.e. those with working status, have above average income and have no expenditure on unhealthy commodities. 
The lowest average probability is $52.44 \%$, i.e. those with non-work status, below-average income, and having expenses for unhealthy commodities. Poorer people die younger and are sicker than richer people; indeed, mortality and morbidity rates are inversely related to many correlates of socioeconomic status such as income, wealth, education, or social class (Deaton, 2002).

After all, prepare for aging population is important for a country. Various aspects of economic burden are associated with an aging population: social security payments will increase, medical care insurance costs will grow, the burden associated with uncovered medical expenses such as pharmaceuticals will become quite serious, and long-term care costs will grow (Knickman and Snell, 2002). While every elder has to prepare for aging shocks such as uncovered costs of prescription drugs or the costs of medical care that are not paid by public or private insurance. The better economic condition of an elderly, the preparation for any health costs will be better too.

The need for income security during retirement, now an increasingly lengthy and important segment of life for many, is an important concern in developed societies. Providing income security has raised two critical policy challenges: (1) ensuring that individuals have sufficient income during retirement to avoid a sharp decline in living standards and (2) ensuring that elderly people are sheltered from financial risks. Policymakers need better data on the economic behavior of elderly populations, such as their saving behavior (DaVanzo, 2001).

\section{CONCLUSION}

In conclusion, the condition of wealth represented by income, improves the health condition of the elderly. Those who work in the elderly are also found to have a better level of health than those who have retired or are not working. The elderly population can still be a potential human resource, there are still many elderly people who 
in their old age are the backbone of the family and must be economically responsible for all household members. On the other hand, the health condition of the elderly which tends to decrease with increasing age can cause a potential inhibiting factor for the elderly.

Therefore, it is recommended for the government to consistently implement efforts to improve social welfare for the elderly, so as to support health aging and active aging. Further research is needed to understand better the intercourse. Wealth might cause health, health might cause wealth, or both might be correlated with other factors; indeed, all three possibilities might be operating simultaneously.

\section{REFERENCE}

Badan Pusat Statistik (BPS). 2019. Statistik Penduduk Lanjut Usia 2019. Jakarta: Badan Pusat Statistik Nasional.

Belgrave LL, Haug MR, Gomez-Bellenge FX. 1987. Gender and race differences in effects of health and pension on retirement before 65. Comprehensive Gerontology [B]. 1(3):109-17.
Benzeval, M., Bond, L., Campbell, M., Egan, M., Lorenc, T., Petticrew, M., \& Popham, F. 2014. How does money influence health?. Project Report. Joseph Rowntree Foundation, York.

Bhattacharya, Jayanta, Janet Currie, and Steven Haider. 2004. Poverty, Food Insecurity, and Nutritional Outcomes in Children and Adults. Journal of Health Economics 23 (4): 839-62.

Block, S. 2010. Work and Health: Exploring the impact of employment on health disparities. The Wellesley Institute.

Brulle, Robert J., and David N. Pellow. 2006. Environmental Justice: Human Health and Environmental Inequalities. Annual Review of Public Health 27: 103-24

Dahmann, Nicholas, Jennifer Wolch , Pascale Joassart-Marcelli, Kim Reynolds, and Michael Jerrett. 2010. The Active City? Disparities in Provision of Urban Public Recreation Resources. Health Place 16 (3): 431-45.

Darmojo, Boedhi., Martono, Hadi.,dkk., 2010 , Buku Ajar Geriatri. Edisi ke - 4, Jakarta: Balai Penerbit FKUI

Dave, D., Rashad, I., \& Spasojevic, J. 2006. The effects of retirement on physical and mental health outcomes (No. w12123). National Bureau of Economic Research. 
DaVanzo, Julie. 2001 Preparing for an Aging World. Santa Monica, CA: RAND

Corporation. https://www.rand.org/pubs/r esearch_briefs/RB5058.html.

Deaton, A. 2002. Policy implications of the gradient of health and wealth. Health affairs, 21(2), 1330.

Doubeni, C. A., M. Schootman, J. M. Major, R. A. Stone, A. O. Laiyemo, Y. Park, M. Lian, L. Messer, B. I. Graubard, R. Sinha, A. R. Hollenbeck, and A. Schatzkin. 2012. Health Status, Neighborhood Socioeconomic Context, and Premature Mortality in the United States: The National Institutes of Health-AARP Diet and Health Study. American Journal of Public Health 102 (4): 680-8

Feinstein, J.S. \& Ho, C.C. 2000. Elderly Asset Management and Health: An Empirical Analysis. Yale School of Management Working Paper No. H-8.

Kim, J. E., \& Moen, P. 2002. Retirement transitions, gender, and psychological well-being: A lifecourse, ecological model. The Journals of Gerontology Series B: Psychological Sciences and Social Sciences, 57(3), P212-P222.

Knickman, J. R., \& Snell, E. K. 2002. The 2030 problem: caring for aging baby boomers. Health services research, 37(4), 849-884.

Lancaster, L. C. and Stillman, D. 2002. When Generations Collide. Who
They Are. Why They Clash. How to Solve the Generational Puzzle at Work. New York: Collins Business.

Loilgen, H., Böckenhoff, A., Knapp, G., 2009. Physical activity and allcause mortality: an updated meta-analysis with different intensity categories. Int. J. Sports Med. 30 (03), 213-224

Mannheim, K. 1952. The Problem of Generations. Essays on the Sociology of Knowledge, 24(19), 276-322-24.

Marmot M. 1999. Multi-Level Approaches to Understanding Social Determinants. Social Epidemiology. Berkman L and Ichiro K, eds. Oxford: Oxford University Press

Martin, C. A. and Tulgan, B. 2002. Managing the Generational Mix. Amherst, MA: HRD Press.

Maryam, Siti. 2010. Asuhan Keperawatan Pada Lansia. Jakarta: Trans Info Medika

McGarry K. 2004. Health and retirement: do changes in health affect retirement expectations? Journal of Human Resources. 39(3):624-48.

Mohai, Paul, Paula M. Lanz, Jeffrey Morenoff, James S. House, and Richard P. Mero. 2009. Racial and Socioeconomic Disparities in Residential Proximity to Polluting Industrial Facilities: Evidence from the Americans' Changing Lives Study. American 
Journal of Public Health 99 (suppl 3): S649-S56.

Morland, Kimberley, and Susan Filomena. 2007. Disparities in the Availability of Fruits and Vegetables between Racially Segregated Urban Neighbourhoods. Public Health Nutrition 10 (12): 1481-9.

Mueller, J. T., Park, S. Y., \& Mowen, A. J. 2019 a. The relationship between parks and recreation per capita spending and mortality from 1980 to 2010: a fixed effects model. Preventive medicine reports, 14, 100827.

Mueller, J. T., Park, S. Y., \& Mowen, A. J. 2019 b. The relationship between self-rated health and local government spending on parks and recreation in the United States from 1997 to 2012. Preventive medicine reports, 13, 105-112.

Nasir, Sudirman. 2015. Indonesia at 70: Prepare for aging population. At The Jakarta Post Saturday, August 15, 2015, Retrieved from https://www.thejakartapost.co $\mathrm{m} /$ news/2015/08/15/indonesi a-70-prepare-agingpopulation.html

NCBI / National Research Council (US) Panel on a Research Agenda and New Data for an Aging World. 2001. Preparing for an Aging World: The Case for CrossNational Research. Washington (DC): National Academies Press (US); 6, The Health of Aging
Populations. Available from: https://www.ncbi.nlm.nih.gov /books/NBK98373/

Nocon, M., Hiemann, T., MullerRiemenschneider, F., Thalau, F., Roll, S., Willich, S.N., 2008. Association of physical activity with all-cause and cardiovascular mortality: a systematic review and metaanalysis. Eur. J. Cardiovasc. Prev. Rehabil. 15 (3), 239-246.

Ogg, J. and Bonvalet, C., 2011. Baby boomers: a mobile generation. Oxford: The Bardwell Press.

Park, B. H., Jung, M., \& Lee, T. J. 2009. Associations of income and wealth with health status in the Korean elderly. J Prev Med Public Health, 42(5), 275-282.

Putnam R. 2000. Bowling alone: the collapse and revival of American community. Simon \& Schuster: New York.

Saffer H. 2005. The demand for social interaction. NBER Working Paper No.11881.

Salman, D. M., \& Atya, E. M. 2012. Relation between Health and Wealth: Is it a Myth or a True Relationship? Evidence from Egypt. European Journal of Economics, Finance and Administrative Sciences, (51).

Tajvar, M., Arab, M., \& Montazeri, A. 2008. Determinants of healthrelated quality of life in elderly in Tehran, Iran. BMC public health, 8(1), 323. 
Tiainen, Marta. 2018. The relationship between wealth and health. Master's Thesis University of Helsinki Faculty of Social Science Economics, retrieved from

https:/ / helda.helsinki.fi/bitstre am/handle/10138/235945/Tiai nen_Economics.pdf? sequence $=2$

Undang-Undang Nomor 13 Tahun 1998 tentang Kesejahteraan Lanjut Usia

Woolf, S. H., Sarah M Simon, Laudan Aron, Emily Zimmerman, Lisa Dubay, Kim X Luk. 2015. How are income and wealth linked to health and longevity?. Income and Health Initiative: Brief One. Urban Institute.

Zhang, Xingyou, Robert L. Phillips, Jr., Andrew W. Bazemore, Martey S. Dodoo, Stephen M. Petterson, Imam Xierall, and Larry A. Green. 2008. Physician Distribution and Access: Workforce Priorities. American Family Physician 77 (10): 1378 